Journal of Advanced Research in Applied Sciences and Engineering Technology

\title{
Improving Energy Efficiency in the Supermarket by Retrofitting Low E Glass Doors for Open Refrigerated
}

\author{
Piyanut Saengsikhiao ${ }^{1}$, Juntakan Taweekun ${ }^{2,}{ }^{*}$, Kittinan Maliwan ${ }^{2}$, Somchai Sae-ung ${ }^{2}$, \\ Thanansak Theppaya² \\ 1 Energy Technology Program, Faculty of Engineering, Prince of Songkla University, Hat Yai, Songkhla 90112, Thailand \\ 2 Department of Mechanical Engineering, Faculty of Engineering, Prince of Songkla University, Hat Yai, Songkhla 90112, Thailand
}

\section{ABSTRACT}

This research presents the improving energy efficiency by retrofitting doors for open refrigerated in central Thailand supermarkets that open in the daytime (06.00 am - 6:00 pm) and close in night-time (00.00 am - 6:00 am). The Materials and Methods were open refrigerated 15 cabinet and retrofitting doors for open refrigerated that 41 frames, 82 doors in medium temperature refrigeration system and measure power consumption $\mathrm{kW}, \mathrm{kWh}$ by power meter data logger for analysis and summarize. The power consumption saving average per 7 days for retrofitting doors was $576 \mathrm{kWh} /$ day, 39.67\% that daytime $418 \mathrm{kWh} /$ day, $41.93 \%$, and night-time $116 \mathrm{kWh} /$ day, 33.24\%. Besides, the energy of day time more than night time because 1) The time of opening store is longer than closing store 2) In the night time, the refrigerated will close by plastic curtain 3) The request cooling load of day time is longer than day time 4) The sale area/ambient temperature of night time more than day time but the humidity was contrasted. Before retrofitting doors, the maximum and minimum of power consumption was $83.25 \mathrm{kw} / \mathrm{hour}$ and $44.73 \mathrm{kw} / \mathrm{hour}$, respectively. Also, the power consumption swing at $38.52 \mathrm{kw} / \mathrm{hour}, 46.72 \%$, and the maximum and minimum of power consumption after retrofitting doors was $33.15 \mathrm{kw} / \mathrm{hour}$ and $30.19 \mathrm{kw} / \mathrm{hour}$, respectively. The power consumption swing at $2.96 \mathrm{kw} / \mathrm{hour}, 8.93 \%$. In addition, the power consumption swing will after be retrofitting doors will less than before retrofitting doors by 1) The average cooling load will be the same as bolt conditions 2) The request cooling load of doors refrigerated will less than by product load, the swing of sale area temperature and humidity, customer behavior that effect power condition will have the low running operation. This research's investment was 21,694 $€$, while the payback period of this research was 14 months. Besides, within 1.1 years, that energy saving was $16,020 \mathrm{kWh} /$ Month or $1,542 € /$ Month, $16,020 \mathrm{kWh} /$ month or $192,220 \mathrm{kWh} /$ Year or $18,503 € /$ Year.

\section{Keywords:}

Refrigeration system; Energy efficiency;

Low E glass doors; open refrigerated;

retrofitting

Copyright @ 2020 PENERBIT AKADEMIA BARU - All rights reserved

\section{Introduction}

Energy use in Thailand's business sector is ranked second among overall energy users in the country and is thus being targeted for energy-saving options [1]. The number of supermarkets in Thailand is numbered to more than 1,500 locations in 2020, which continuously increases annually [2]. The majority are open 18-24 hours per day, so the retail sector is the fourth largest consumer of energy in the business sector, consuming more energy than residences do [3]. The components that

\footnotetext{
* Corresponding author.

E-mail address: jantakan.t@psu.ac.th, juntakan2016@gmail.com (Juntakan Taweekun)
}

https://doi.org/10.37934/araset.20.1.1117 
contribute to supermarkets' energy consumption in Thailand, ranked from highest to lowest, are refrigeration systems, air-conditioning systems, electrical equipment, and lighting [4-5]. However, proportions of energy use in the supermarkets in Thailand were previously ranked, as shown in Figure 1 below [6]. The best options for reducing energy consumption in supermarkets in Thailand are high energy efficiency and an efficient energy-management system. An excellent example of energy savings in refrigeration systems is shown in Figure 2 below [7]. Energy savings in refrigeration systems can be achieved through decreased power consumption of the compressor, as this is the component that utilizes the most energy.
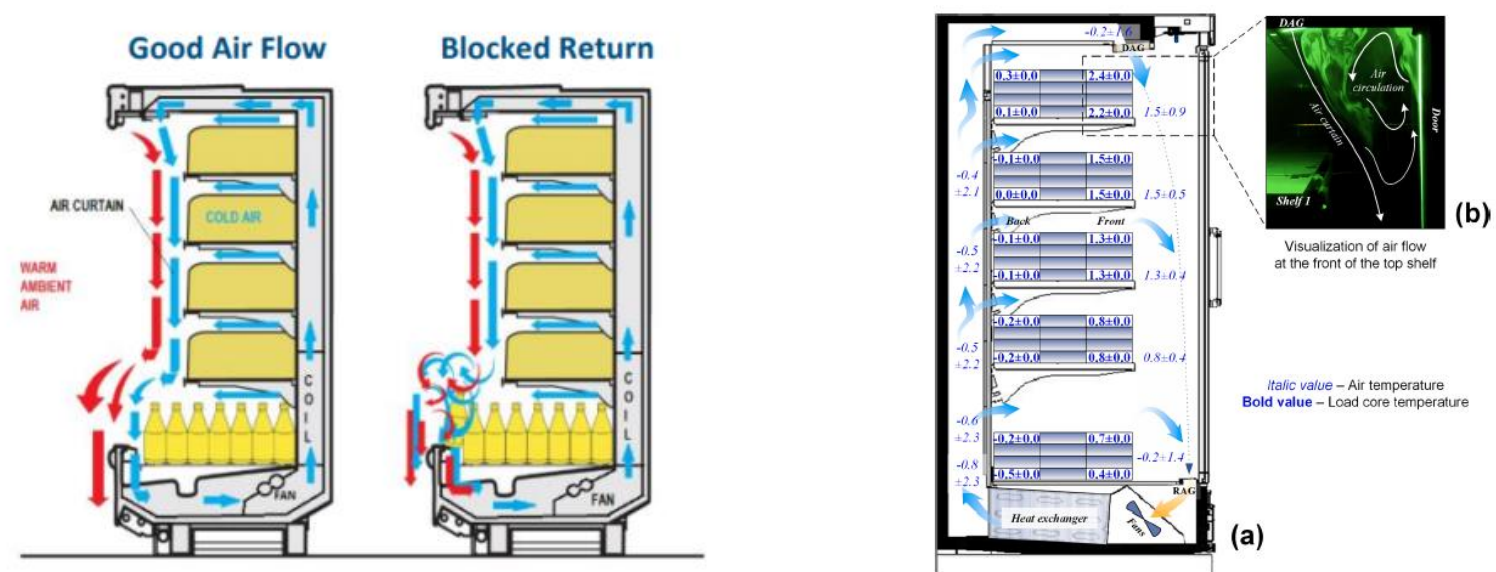

Fig. 1. How to open and close refrigerated operated [8-9]

The open showcase can keep the cabinet's temperature by air curtain systems, as shown in Figure 1 [8-9]. The airflow supply was sperate by $70 \%$ for air curtains that keep the temperature and $30 \%$ for airflow supply at back wall panel that product cooling. Besides, Bolt airflow supply will comeback $100 \%$ at return gill and operating continuously. If there is some condition effect to air curtain, for example, 1) Something block return supply 2) Customer pick product 3) Sales area temperate and humidity 4) Wind form air condition return and supply, and 5) Staff Storage that effect to the performance of refrigerated and power consumption of compressor [10-11]. For the refrigerated with doors that can operate and perform better than open refrigerated [12-13] because there are no 5 effect conditions as before, as shown in Figure 2 below [14]. The comparison of cabinet temperature simulation with open refrigerated and doors refrigerated, that doors refrigerated can keep the temperature. Also, the minimum temperate and maximum temperature does not swing. This research will present improving energy efficiency by retrofitting doors for open refrigerated in central Thailand supermarkets. Thus, customers can get good quality products, while retail companies and suppliers can get reliability.
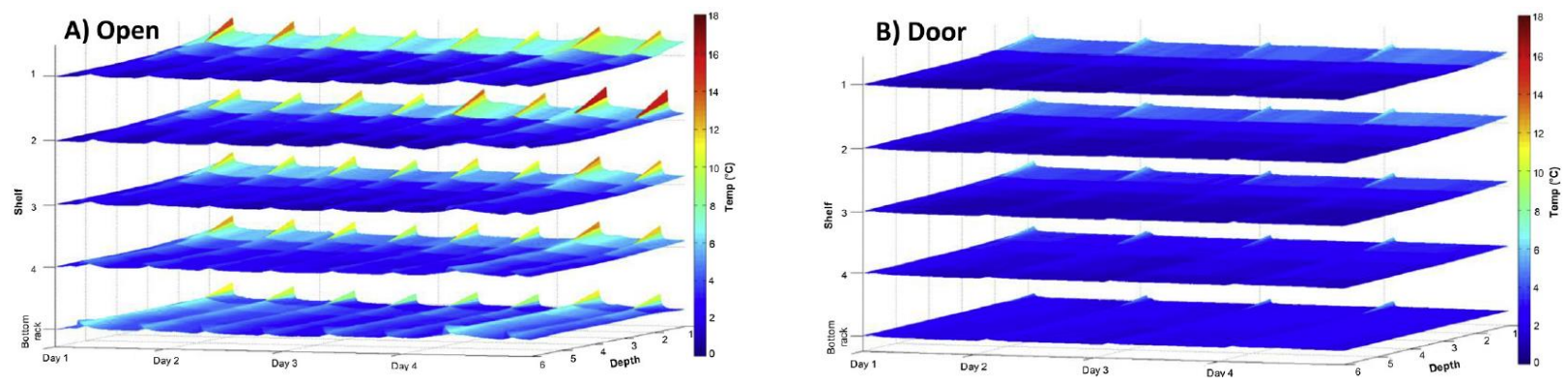

Fig. 2. Cabinet temperature compare with close and open refrigerated [15] 


\section{Materials and Methods}

The Low E glass door for cabinet will reduce the power consumption of compressor to protect heating or cooling, as shown in Figure 3 below. The Low E will be a coating that filler for reducing transmission and absorption of infrared [16-17]. The most common type of a Low-E window uses two or three panes of glass, with a gas gap between them in the fridge [18-19]. The performance is to reduce transmission and absorption of infrared will hill and cost [20]. This research used Low-E glass two-layer with a gas gap for retrofits to open refrigerated, as showed in the fridge, the percentage of transmission for Low-E glass at all layer types lower than regular glass shown in Figure 4 below [21].

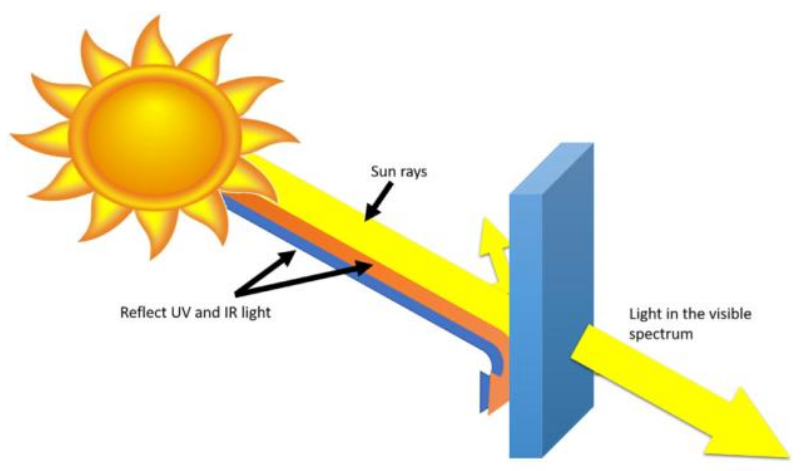

Fig. 3. Low-E filters on windows [21]

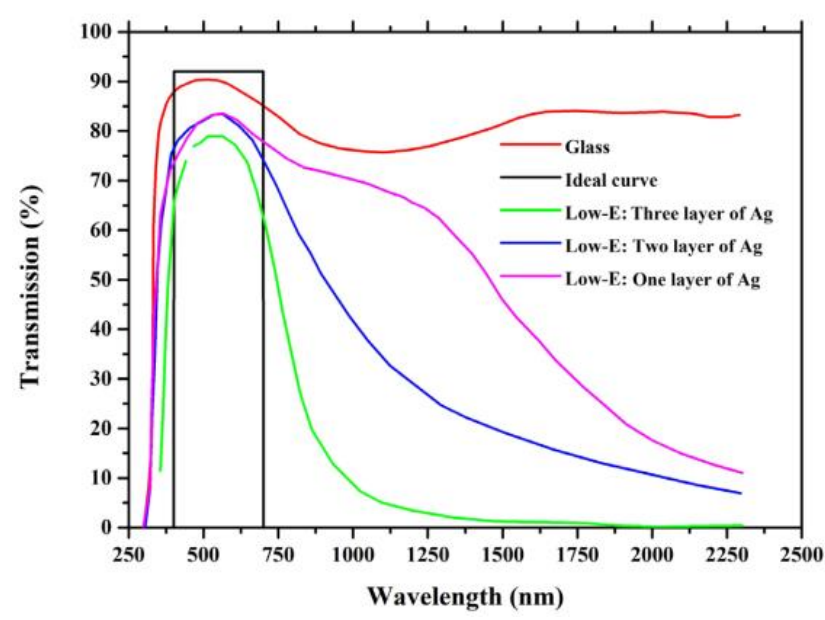

Fig. 4. Transmittance of different Low-E filters [21]

The 15 cabinets of open refrigerated and retrofitting doors are using for open refrigerated with 41 frames, 82 doors in medium temperature refrigeration system summarize in Table 1 . The cabinet type was for sausage, dairy, and meat products that evaporated the temperature at $-8,-8,-10$ degrees Celsius, and cabinet temperate $(+2 /+4),(+2 /+4),(+0 /+2)$ degrees Celsius, respectively. The cabinet dimensions were $3750 \mathrm{Lx} 800 \mathrm{D} \times 2000 \mathrm{H}$ and $2500 \mathrm{Lx} 800 \mathrm{D} \times 2000 \mathrm{H}$, which having 3 frames, 6 doors, and 2 frames 4 doors, respectively. The result reveals the measurement of power consumption in $\mathrm{kW}, \mathrm{kWh}$ by power meter analysis for data logger, and the summary of medium temperature refrigeration system. The picture for retrofitting doors for open refrigerated as showed in Figures 5 and 6. 
Table 1

Cabinet Detail in supermarket

\begin{tabular}{|c|c|c|c|c|c|c|c|}
\hline No. & DESCRIPTION & DIMENSION MM & $\begin{array}{l}\text { Cabinet Temp } \\
{ }^{\circ} \mathrm{C}\end{array}$ & $\begin{array}{l}\text { Evap Temp } \\
{ }^{\circ} \mathrm{C}\end{array}$ & $\begin{array}{l}\text { MT Cooling load } \\
\text { kW }\end{array}$ & $\begin{array}{l}\text { Retrofits } \\
\text { Frames }\end{array}$ & Doors \\
\hline 1 & Sausage No.1 & $3750 \mathrm{Lx} 800 \mathrm{D} \times 2000 \mathrm{H}$ & $(+2 /+4)$ & -8 & 5.08 & 3 & 6 \\
\hline 2 & Sausage No.2 & $3750 \mathrm{Lx} 800 \mathrm{D} \times 2000 \mathrm{H}$ & $(+2 /+4)$ & -8 & 5.08 & 3 & 6 \\
\hline 3 & Sausage No.3 & $3750 \mathrm{Lx} 800 \mathrm{D} \times 2000 \mathrm{H}$ & $(+2 /+4)$ & -8 & 5.08 & 3 & 6 \\
\hline 4 & Sausage No.4 & $2500 \mathrm{Lx} 800 \mathrm{D} \times 2000 \mathrm{H}$ & $(+2 /+4)$ & -8 & 3.4 & 2 & 4 \\
\hline 5 & Dairy No.1 & $3750 \mathrm{Lx} 800 \mathrm{D} \times 2000 \mathrm{H}$ & $(+2 /+4)$ & -8 & 5.08 & 3 & 6 \\
\hline 6 & Dairy No.2 & $3750 \mathrm{Lx} 800 \mathrm{Dx} 2000 \mathrm{H}$ & $(+2 /+4)$ & -8 & 5.08 & 3 & 6 \\
\hline 7 & Dairy No.3 & $3750 \mathrm{Lx} 800 \mathrm{D} \times 2000 \mathrm{H}$ & $(+2 /+4)$ & -8 & 5.08 & 3 & 6 \\
\hline 8 & Dairy No.4 & $3750 \mathrm{Lx} 800 \mathrm{D} \times 2000 \mathrm{H}$ & $(+2 /+4)$ & -8 & 5.08 & 3 & 6 \\
\hline 9 & Dairy No.5 & $2500 \mathrm{Lx} 800 \mathrm{D} \times 2000 \mathrm{H}$ & $(+2 /+4)$ & -8 & 3.4 & 2 & 4 \\
\hline 10 & Dairy No.6 & $2500 \mathrm{Lx} 800 \mathrm{D} \times 2000 \mathrm{H}$ & $(+2 /+4)$ & -8 & 3.4 & 2 & 4 \\
\hline 11 & Meat No.1 & $3750 \mathrm{Lx} 800 \mathrm{D} \times 2000 \mathrm{H}$ & $(+0 /+2)$ & -10 & 5.7 & 3 & 6 \\
\hline 12 & Meat No.2 & $3750 \mathrm{Lx} 800 \mathrm{D} \times 2000 \mathrm{H}$ & $(+0 /+2)$ & -10 & 5.7 & 3 & 6 \\
\hline 13 & Meat No.3 & $3750 \mathrm{Lx} 800 \mathrm{D} \times 2000 \mathrm{H}$ & $(+0 /+2)$ & -10 & 5.7 & 3 & 6 \\
\hline 14 & Meat No.4 & $3750 \mathrm{Lx} 800 \mathrm{D} \times 2000 \mathrm{H}$ & $(+0 /+2)$ & -10 & 5.7 & 3 & 6 \\
\hline 15 & Meat No.5 & $2500 \mathrm{Lx} 800 \mathrm{D} \times 2000 \mathrm{H}$ & $(+0 /+2)$ & -10 & 3.82 & 2 & 4 \\
\hline
\end{tabular}
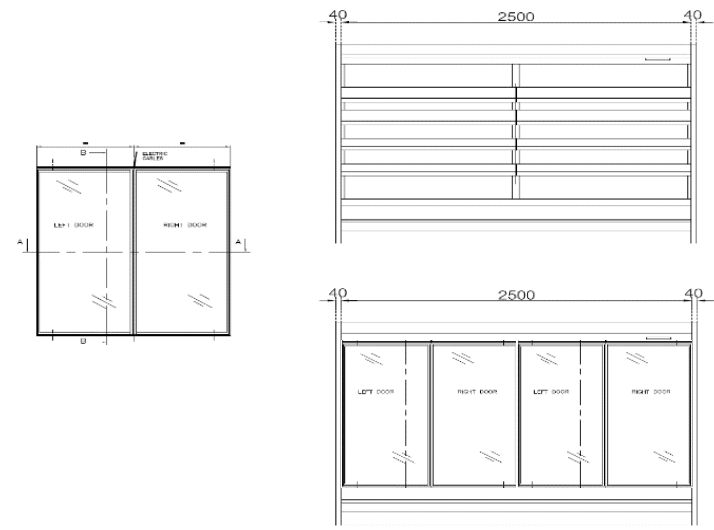

Fig. 5. Doors and refrigerated drawing

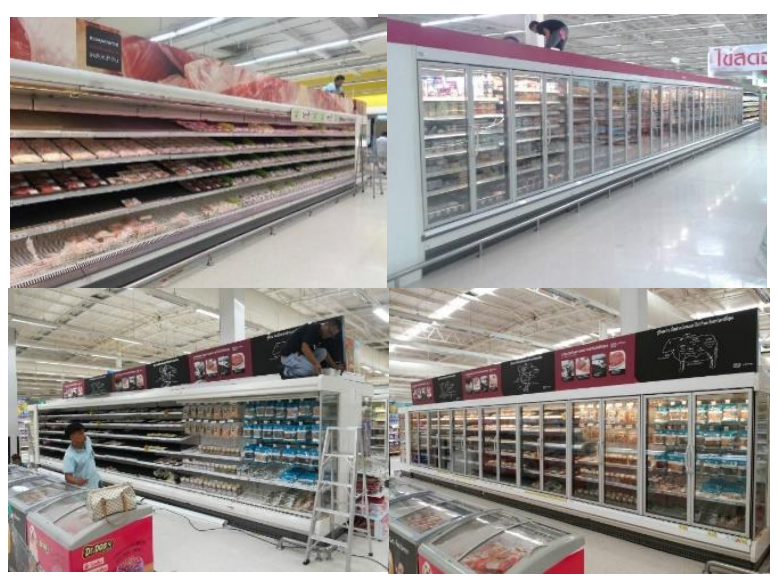

Fig. 6. Before and after retrofits doors

\section{Results and Discussion}

The power consumption before and after retrofitting doors in Figure 7 shows power consumption in daytime operation $(06.00 \mathrm{am}-6: 00 \mathrm{pm})$ and when supermarket close and night-time $(00.00 \mathrm{am}-$ 6:00 am). Before retrofitting doors, the average power consumption per 7 day was 1,388 kwh/day that daytime $997 \mathrm{kWh} /$ day and night-time $391 \mathrm{kWh} /$ day. After retrofitting doors, the average power consumption per 7 day was $812 \mathrm{kwh} /$ day that daytime $579 \mathrm{kWh} /$ day and night-time $233 \mathrm{kWh} /$ day. The power consumption saving average per 7 day for retrofitting doors was $576 \mathrm{kWh} /$ day, which is different by $39.67 \%$ from daytime and $418 \mathrm{kWh} /$ day, which is different by $41.93 \%$ and night-time was $33.24 \mathrm{kWh} /$ day. Besides, the energy of day time is more than night time because of 1) The time for opening store is longer than closing time 2) In night time the refrigerated will close by plastic curtain 3) The request cooling load of day time more than night time, and 4) The sale area/ambient temperature of night time more than day time, however, the humidity was contrasted. 

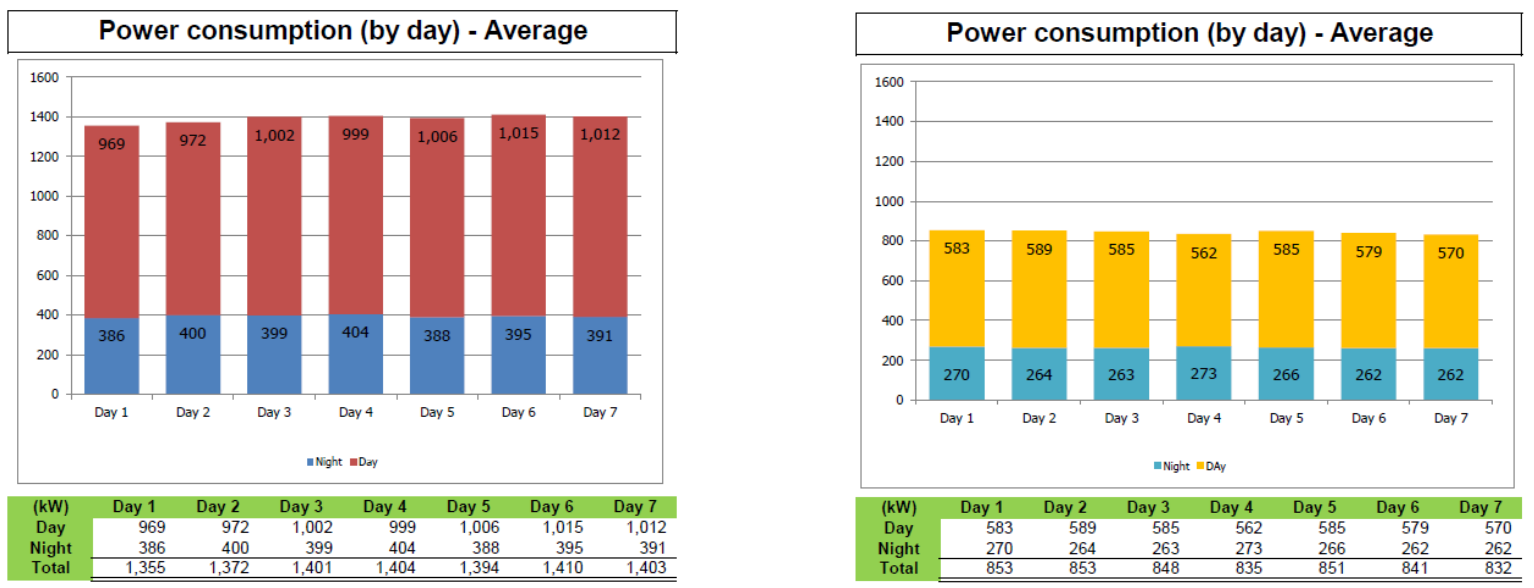

Fig. 7. Before and after retrofits doors power consumption average/day

Before retrofitting doors, the average power consumption per 7 days was $111.62 \mathrm{kw} /$ day, daytime was at $62.29 \mathrm{~kW} /$ day, and night-time was at $49.33 \mathrm{~kW} /$ day. After retrofitting doors, the average power consumption per 7 days was $69.48 \mathrm{~kW} /$ day, daytime was at $36.33 \mathrm{~kW} /$ day, and nighttime was at $33.15 \mathrm{~kW} /$ day, as showed in Figure 8. The maximum and minimum of power consumption before retrofitting doors was $83.25 \mathrm{kw} /$ hour and $44.73 \mathrm{kw} / \mathrm{hour}$, respectively. That power consumption swing at $38.52 \mathrm{kw} / \mathrm{hour}, 46.72 \%$, and the maximum and minimum of power consumption after retrofitting doors was at $33.15 \mathrm{kw} /$ hour and $30.19 \mathrm{kw} / \mathrm{hour}$, respectively, that power consumption swing at $2.96 \mathrm{kw} /$ hour, or $8.93 \%$. The power consumption swing after retrofitting doors will less than before retrofitting doors because of 1) The normal cooling load will same of bolt conditions 2) The request cooling load of doors refrigerated will less than by product load, the swing of sale area temperature and humidity. Also, the effect of customer behaviour towards the power condition will low running operate.
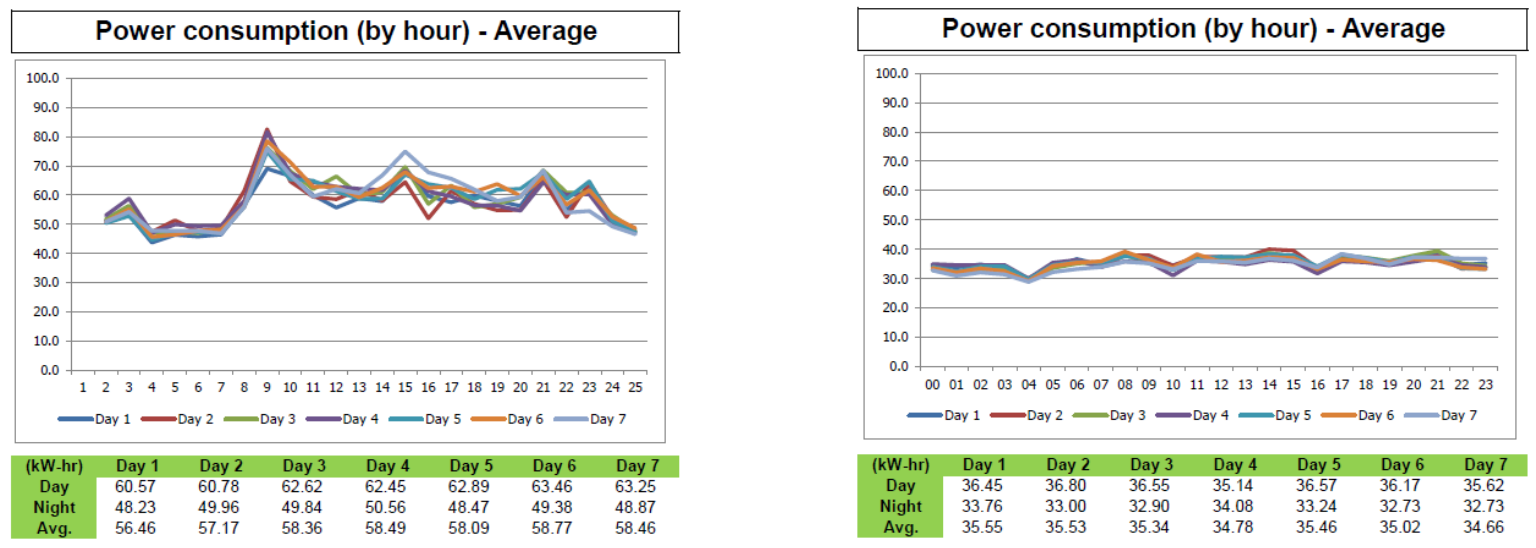

Fig. 8. Before and after retrofits doors power consumption average/hour

The investment for this research was $21,694 €$ with 41 frames or 82 doors. The payback period of this research was 14 Months. Besides, within 1.1 year, the energy saving 16,020 kWh/Month or 1,542 $€ /$ Month, as well as16,020 kWh/month or 192,220 kWh/Year, which counted as 18,503 €/Year. Besides, the energy saving per frames and energy saving per doors was 4,689 kWh/Year or $451 € /$ Year and $2,344 \mathrm{kWh} /$ Year or $225 € /$ Year, respectively. 


\section{Conclusions}

For further recommendations, the researchers should apply the retrofitting doors for another open refrigerated, such as horizontal refrigerated and other door types. For example, use slide door that is resulting in energy saving and retrofitting doors to open another refrigerated in the convenience store, which can get energy-saving from 20,000 stores all over Thailand.

\section{Acknowledgement}

This study was supported by Prince of Songkla University and SANYO S.M.I. (Thailand) Co., Ltd. This research was funded by Prince of Songkla University and SANYO S.M.I. (Thailand) Co., Ltd.

\section{References}

[1] Kuo, Chung-Feng Jeffrey, Chieh-Hung Lin, and Ming-Hao Lee. "Analyze the energy consumption characteristics and affecting factors of Taiwan's convenience stores-using the big data mining approach." Energy and Buildings 168 (2018): 120-136. https://doi.org/10.1016/i.enbuild.2018.03.021

[2] Saengsikhiao, Piyanut, Juntakan Taweekun, Kittinan Maliwan, Somchai Sae-ung, and Thanansak Theppaya. "Investigation and Analysis of R463A as an Alternative Refrigerant to R404A with Lower Global Warming Potential." Energies 13, no. 6 (2020): 1514. https://doi.org/10.3390/en13061514

[3] Shen, Hanyan, Ke Xu, and James Freihaut. "A statistical study on energy performance of US convenience stores: Investigation of factors and bench marking on store energy use." Energy and Buildings 183 (2019): 792-802. https://doi.org/10.1016/i.enbuild.2018.10.018

[4] Tassou, S. A., Y. Ge, A. Hadawey, and Doug Marriott. "Energy consumption and conservation in food retailing." Applied Thermal Engineering 31, no. 2-3 (2011): 147-156.

https://doi.org/10.1016/i.applthermaleng.2010.08.023

[5] Wang, An-Ping, and Pau-Lo Hsu. "The network-based energy management system for convenience stores." Energy and buildings 40, no. 8 (2008): 1437-1445.

https://doi.org/10.1016/i.enbuild.2008.01.007

[6] Chou, Ding-chin, Ching-Shan Chang, and Yong-Zhi Hsu. "Investigation and analysis of power consumption in convenience stores in Taiwan." Energy and Buildings 133 (2016): 670-687. https://doi.org/10.1016/j.enbuild.2016.10.010

[7] Evans, J. A., E. C. Hammond, A. J. Gigiel, A. M. Fostera, L. Reinholdt, K. Fikiin, and C. Zilio. "Assessment of methods to reduce the energy consumption of food cold stores." Applied Thermal Engineering 62, no. 2 (2014): 697-705. https://doi.org/10.1016/i.applthermaleng.2013.10.023

[8] Chaomuang, Nattawut, Onrawee Laguerre, and Denis Flick. "Dynamic heat transfer modeling of a closed refrigerated display cabinet." Applied Thermal Engineering 161 (2019): 114138. https://doi.org/10.1016/i.applthermaleng.2019.114138

[9] Chaomuang, Nattawut, Onrawee Laguerre, and Denis Flick. "A simplified heat transfer model of a closed refrigerated display cabinet." Thermal Science and Engineering Progress 17 (2020): 100494. https://doi.org/10.1016/i.tsep.2020.100494

[10] Evans, J. A., S. Scarcelli, and M. V. L. Swain. "Temperature and energy performance of refrigerated retail display and commercial catering cabinets under test conditions." International Journal of Refrigeration 30, no. 3 (2007): 398-408. https://doi.org/10.1016/j.ijrefrig.2006.10.006

[11] D'Agaro, P., G. Croce, and G. Cortella. "Numerical simulation of glass doors fogging and defogging in refrigerated display cabinets." Applied thermal engineering 26, no. 16 (2006): 1927-1934. https://doi.org/10.1016/i.applthermaleng.2006.01.014

[12] de Frias, J. Atilio, Yaguang Luo, Bin Zhou, Boce Zhang, David T. Ingram, Keith Vorst, Jeffrey K. Brecht, and John Stommel. "Effect of door opening frequency and duration of an enclosed refrigerated display case on product temperatures and energy consumption." Food Control 111 (2020): 107044. https://doi.org/10.1016/i.foodcont.2019.107044 
[13] Månsson, Tommie, Adones Rukundo, Magnus Almgren, Philippas Tsigas, Christian Marx, and York Ostermeyer. "Analysis of door openings of refrigerated display cabinets in an operational supermarket." Journal of Building Engineering 26 (2019): 100899. https://doi.org/10.1016/i.jobe.2019.100899

[14] Chaomuang, Nattawut, Denis Flick, Alain Denis, and Onrawee Laguerre. "Experimental analysis of heat transfer and airflow in a closed refrigerated display cabinet." Journal of Food Engineering 244 (2019): 101-114. https://doi.org/10.1016/i.jfoodeng.2018.09.009

[15] de Frias, J. Atilio, Yaguang Luo, Liping Kou, Bin Zhou, and Qin Wang. "Improving spinach quality and reducing energy costs by retrofitting retail open refrigerated cases with doors." Postharvest Biology and Technology 110 (2015): $114-120$ https://doi.org/10.1016/i.postharvbio.2015.06.016

[16] DeVetter, Brent M., Seth Kenkel, Shachi Mittal, Rohit Bhargava, and Tomasz P. Wrobel. "Characterization of the structure of low-e substrates and consequences for IR transflection measurements." Vibrational Spectroscopy 91 (2017): 119-127. https://doi.org/10.1016/i.vibspec.2016.09.001

[17] Han, Jun, Lin Lu, and Hongxing Yang. "Numerical evaluation of the mixed convective heat transfer in a double-pane window integrated with see-through a-Si PV cells with low-e coatings." Applied Energy 87, no. 11 (2010): 34313437. https://doi.org/10.1016/i.apenergy.2010.05.025

[18] Schaefer, C., G. Bräuer, and J. Szczyrbowski. "Low emissivity coatings on architectural glass." Surface and Coatings Technology 93, no. 1 (1997): 37-45. https://doi.org/10.1016/S0257-8972(97)00034-0

[19] Solovyev, A. A., S. V. Rabotkin, and N. F. Kovsharov. "Polymer films with multilayer low-E coatings." Materials Science in Semiconductor Processing 38 (2015): 373-380. https://doi.org/10.1016/i.mssp.2015.02.051

[20] Ghosh, S. S., Biswas, P. K., \& Neogi, S. (2017). Thermal performance of solar cooker with special cover glass of lowe antimony doped indium oxide (IAO) coating. Applied Thermal Engineering, 113, 103-111. https://doi.org/10.1016/i.applthermaleng.2016.10.185

[21] Abundiz-Cisneros, N., R. Sanginés, R. Rodríguez-López, M. Peralta-Arriola, J. Cruz, and R. Machorro. "Novel Low-E filter for architectural glass pane." Energy and Buildings 206 (2020): 109558.

https://doi.org/10.1016/j.enbuild.2019.109558 